\title{
KECERDASAN BUATAN MANUSIA (ARTIFICIAL INTELLIGENCE): TEKNOLOGI IMPIAN MASA DEPAN
}

\section{Rinien Kusumawati}

Jurusan Teknik Informatika, Fakultas Sains dan Teknologi Universitas Islam Negeri Malang. Jl. Gajayana 50 Malang, telp. 0341-551354. e-mail: m kusumawati@yahoo.com

\begin{abstract}
The computer technology has incredibly increased. Computer software and hardware compete to meet the customer's needs. The research intends to spread the knowledge on information technology, specifically, on the artificial intelligence. The concept of artificial intelligence is adopting and imitating human form, character, and habit which to be implemented on the computer. Using natural approach, the research aims to investigate whether artificial intelligence (AI) will produce the duplication of God's creation. Another important reason of other reaseaches on $A I$ is to create a computer which is smart and able to understand human brain working system. Hence, AI has been designed into more practical with faster CPU, cheaper mass memory, and sophisticated software tool. The concept of integrating AI science or collaborative art among sub-fields of technology will stimulate and lead to futher $A I$ researches, and it will be interesting topic for $A I$ researchers for developing AI technology in the future.
\end{abstract}

Key words: software, hardware, duplication, human, artificial intelligence

Ulul Albab, Vol. 9 No. 2, 2008 


\section{Pendahuluan}

Teknologi komputer terus melaju dengan kecepatan yang sungguh luar biasa. Software dan hardware komputer saling berlomba untuk bisa saling mengisi. Si software menuntut si hardware yang lebih canggih, demikian juga sebaliknya. Dari hasil perlombaan itu, tak heran kalau setiap saat kita sering mendengar dan mengetahui munculnya software dan hardware komputer dengan spesifikasi yang berbeda dengan sebelumnya dan pastinya dengan kemampuan yang lebih canggih pula.

Dalam perkembangannya, komputer difungsikan sebagai alat pengolah data dan penghasil informasi. Bahkan komputer juga turut berperan dalam proses pengambilan keputusan. Tidak puas hanya dengan fungsi tersebut, para ahli komputer masih terus mengembangkan kecanggihan komputer agar dapat memiliki kemampuan seperti seorang manusia. Para ahli komputer sering menyebutnya dengan istilah computer cerdas.

Tampaknya sekarang dengan perkembangan teknologi yang sudah semakin maju, pengolahan komputer berbasis teknologi kecerdasan buatan (Artificial Intelligence) sudah bukan hanya menjadi harapan dan angan-angan belaka, tetapi akan segera menjadi kenyataan dan bisa dioperasikan pada komputer pribadi. Metode-metode penyelesaian masalah dengan mengadopsi bentuk, karakter dan kebiasaan manusia dalam menjalani hidupnya di dunia ini, sekarang lagi banyak dijadikan bahan kajian dan penelitian bagi para ahli komputer, khususnya di bidang teknologi kecerdasan buatan.

Bagaimanapun juga, komputer dan teknologi kecerdasan buatan akan selalu sejalan seiring dengan perjalanan waktu. Komputer memang unggul dalam hal penalaran logis dan perhitungan matematis, sehingga tak heran kalau komputer terus merajai kejuaraan catur dunia. Komputer sudah bisa mengenali wajah manusia dan melakukan pembicaraan yang menarik dalam banyak bahasa. Komputer akan melakukan apa pun yang dapat dilakukan manusia yang bergantung pada perhitungan yang ada pada pemrosesan informasi. 
Komputer memang dapat menghitung, dan mungkin juga dapat menalar, tetapi dapatkah komputer merasakan cinta? Mungkinkah komputer akan berteriak jika ia melihat seseorang yang dikenalinya atau suatu kejadian aneh terjadi di depannya? Mungkinkah komputer bisa mengalami pemaknaan? Mungkinkah komputer buatan manusia ini dapat menirukan manusia buatan Sang Khalik dalam segala bentuk dan aktivitasnya? A u mungkinkah manusia dapat diduplikasi dan bukan hanya sekedar ditiru dalam komputer masa depan?

Semua jawaban dari pertanyaan-pertanyaan itu tentunya sangat tergantung pada hasil perkembangan teknologi kecerdasan buatan melalui riset-risetnya. Besarnya upaya para ahli komputer khususnya bidang kecerdasan buatan yang terus menerus melakukan penelitian untuk mengejar target super besar yaitu menciptakan komputer seperti dan sebaik manusia.

Penelitian ini hendak melakukan studi teoritik berdasarkan informasi dalam pustaka disertai pembahasan mendalam untuk mengetahui teknologi kecerdasan buatan (artificial intelligence) beserta aplikasinya. Studi teoritis dimaksudkan sebagai reinterpretasi terhadap sejumlah ayat (baik al-Qur'an dan al-Hadist yang menerangkannya) yang terkait dengan teknologi kecerdasan buatan (artificial intelligence), sehingga dapat dipahami sebagaimana bahasa ilmu pengetahuan dan teknologi yang berlaku saat ini.

\section{Akal Manusia}

Kamus Besar Bahasa Indonesia ( $\mathrm{KBBI})$ mengartikan akal dengan empat pengertian: (1) Daya pikir (untuk mengerti), pikiran, ingatan; (2) jalan atau cara melakukan sesuatu, daya upaya, ikhtiar; (3) tipu daya, muslihat, kecerdikan, kelicikan; dan (4) kemampuan melihat, atau caracara memahami lingkungan.

Kamus-kamus bahasa Arab, secara harfiah mengartikan akal sebagai pengertian alimsak (menahan), alribath (ikatan), alhijr (menahan), al-nahy (melarang), dan man'u (mencegah). Ibn Manzhur, misalnya, mengartikan 
al'aql dengan enam macam : (1) akal pikiran, inteligensi, (2) menahan, (3) mencegah, (4) membedakan, (5) tambang pengikat, dan (6) ganti rugi. Akal juga sering disamakan dengan al-hijr (menahan atau mengikat). Sehingga seorang yang berakal adalah orang yang dapat menahan diri dan mengekang hawa nafsunya. Kata-kata Hamka - seorang ulama-sastrawan Indonesia - mewakili pengertian itu : mengikat binatang dengan tali, mengikat manusia dengan akalnya. (Pasiak, 2003: 193).

Al-Qur'an juga mengajak akal manusia untuk senantiasa ber-tafakur dan ber-tadzakkur akan keberadaan Allah SWT dan ciptaanNya. Dengan adanya akal dan ilmu yang dimilikinya, manusia dapat dibedakan atas golongan yang berilmu dan golongan yang bodoh. Dalam al-Qur'an, Allah SWT menjadikan ilmu sebagai barometer bagi manusia untuk mencapai derajat yang lebih tinggi (ulul albab).

Bahkan Nabi Muhammad SAW juga mengatakan tentang akal bahwa mereka yang tidak menggunakan akalnya dianggap sebagai orang yang tidak beragama, "La dina liman la "aqla lah" (Tidak beragama orang yang tidak menggunakan akalnya). Salah seorang sahabat Nabi Muhammad SAW yang bernama Umar bin Khathab ra pernah berkomentar mengenai akal bahwa : Mahkota seseorang adalah akalnya, derajat seseorang adalah agamanya, dan harga diri seseorang adalah akhlaqnya.

\section{Otak Manusia dan Keistimewaannya}

Kata brain yang berarti otak berasal dari kata Anglo Saxon, braegen. Orang Yunani menyebutnya enkephalos yang menjadi akar asal kata encephalon yang dipakai secara luas dalam ilmu kedokteran untuk menyebut otak. Di bagian luar, otak dibungkus oleh rambut, kulit kepala, tulang tengkorak, duramater, nuangan arachnoid, nuangan subarachnoid, dan piameter (Pasiak, 2002: 64-65).

Secara biologis, otak merupakan pusat bagi semua aktivitas tubuh manusia, baik aktivitas sadar maupun aktivitas tidak sadar. Otak adalah layaknya prosesor dalam CPU (Central Processing Unit) komputer bagi tubuh 
manusia. Otak merupakan satu bagian dari jaringan yang bernama jaringan syaraf, seperti halnya prosesor yang juga merupakan salah satu bagian terpenting dari CPU. Dalam tubuh manusia, selsel membentuk jaringan, jaringan membentuk organ, organ membentuk sistem, dan sistem membentuk manusia. Jalinan bentukan seperti itu juga berlaku dalam komputer.

Dalam beberapa kasus, komputer sengaja dibuat cerdas oleh ahlinya dengan jalan meniru kerja sistem syaraf pada otak manusia. Kecerdasan komputer itu dipengaruhi oleh adanya benda kecil (hardware) yang biasa dikenal dengan sebutan microprosesor, yang sistem kerjanya mengolah data dengan cara yang sedemikian canggih. Prosesor itu boleh kita katakan sebagai otaknya komputer. Tetapi ada baiknya jika kita sadari dan pahami dari awal bahwa seberapapun canggihnya otak komputer itu kita buat, tidak akan pernah menyamai kecanggihan otak manusia buatan Illahi. Bukan main ajaibnya otak manusia yang dalam banyak hal melebihi otak komputer itu. Ayat al-Qur'an berikut dapatlah kita jadikan bahan renungan untuk pengembangan ilmu pengetahuan di masa depan terutama yang berhubungan dengan penduplikasian produk-produk Illahi.

"Sesungguhnya Tuhanmu hanyalah Allah, yang tidak ada Tuhan selain Dia. Pengetahuan-Nya meliputi segala sesuatu" (QS. Thaahaa: 98).

"Allah-lah yang menciptakan tujuh langit dan seperti itu pula bumi. perintah Allah berlaku padanya, agar kamu mengetahui bahwasanya Allah Maha Kuasa atas segala sesuatu, dan Sesungguhnya Allah ilmu-Nya benar-benar meliputi segala sesuatu" (QS. at -Thalaq: 12).

Tidak seperti organ tubuh lain, yang kian tua kian rusak. Otak justru makin tua makin menunjukkan fungsi yang kian luas, dan kian kompleks, serta kian tua intrekoneksi antal sel syaraf (neuron), karena memang pengalaman hidup makin banyak dan makin padat dalam otak manusia. 
Sehingga penyataan makin tua, makin menjadi, sangatlah cocok kalau disandangkan untuk otak manusia.

Otak bekerja memproduksi pikiran atau ide. Produk yang akan tetap bergerak meski orang yang berpikirnya sudah meninggal dunia. Manusia boleh saja mati, tetapi pikiran-pikirannya bisa jadi akan tetap hidup. Seperti Nabi Muhammad SAW dan nabi-nabi lain yang telah wafat. Pikiranpikirannya tidak pernah mati, Beliau tetap dikenang. Bukan hanya pikiran dan ajaran beliau yang dikenang, bahkan pikiran dan ajaran beliau tersebut telah dijadikan pedoman hidup di dunia dan akherat.

\section{Otak Manusia Tiruan}

Dalam hal kemampuan, komputer bisa dipakai untuk menghitung, membuat teks, membuat tabel-tabel, menggambar dan mendesain, serta berbagai aplikasi lainnya. Di dalam komputer juga ada program yang mengendali fungsi-fungsi tersebut. Tentunya ada manusia yang sengaja melakukannya.

Seluruh piranti komputer (hardware) itu hanyalah sekedar fasilitas atau infrastruktur belaka. Yang telah membuat komputer itu berfungsi secara cerdas adalah program-program (software) cerdas yang ada di dalamnya. Baik berupa program operating system, maupun berbagai macam program aplikasi yang di"tanam" di dalam CPU komputer. Dan supaya tercipta software yang cerdas dan kompeter juga bisa bertingkah laku cerdas perlu kecerdasan otak pembuatnya pula (brainware).

Ketika program-program cerdas itu sudah dimasukkan ke dalam otaknya komputer (di CPU - Central Processing Unit), maka komputer itu tinggal berjalan mengikuti fitrahnya saja. Begitu dihidupkan, komputer secara otomatis akan langsung masuk ke dalam program operating systemnya. Dan sesudah itu, komputer baru bisa berfungsi sesuai dengan program aplikasi yang sudah ada dalam komputer itu, tergantung keinginan sang user.

Mekanisme kerja komputer yang demikian itu, kurang lebih serupa pada manusio dan otaknya. Manusia diciptakan Allah SWT dengan 
mengikuti pola tertentu yang biasa disebut sebagai fitrah. Di dalam fitrah dasar itu, manusia diberi kemampuan-kemampuan tertentu agar berfungsi dalam menjalani hidup dan kehidupannya di dunia. Fitrah itulah operating system pada diri manusia. Sedangkan berbagai macam kemampuan dan bakat yang dimiliki manusia adalah program-program aplikasi karunia Allah SWT. Hal ini seperti yang diwahyukan Allah SWT dalam firman-Nya surat ar-Rum ayat 30 .

"Maka hadapkanlah wajahmu dengan lurus kepada agama Allah; (tetaplah atas) fitrah Allah yang Telah menciptakan manusia menurut fitrah itu. tidak ada peubahan pada fitrah Allah. (Itulah) agama yang lurus; tetapi kebanyakan manusia tidak mengetahui" (QS. ar-Rum: 30).

Program dasar di dalam diri manusia adalah operating system yang bersesuaian dengan fitrah Allah SWT itu, yang dinamakan Ruh. Ibaratnya adalah program Windows dalam komputer. Dengan adanya Ruh itu, maka manusia dalam hidupnya sudah berada di dalam sistem operasi yang bersesuaian dengan fitrah Allah SWT. Tinggal, bagaimana dia menjalankan program aplikasinya.

Kesempurnaan manusia sebagai makhluk yang tertinggi itu karena manusia diciptakan 'meniru' fitrah Allah, tapi dalam skala kecil. Dalam istilah di atas : sebagian dari Ruh kami. Karena keberadaan Ruh itulah maka manusia bisa mendengar, bisa melihat, dan bisa merasakan. Proses mendengar, melihat, dan memahami itu sendiri adalah potensi jiwa dengan difasilitasi oleh badan, yaitu panca indera, hati dan berpusatkan di struktur otak

Komputer tidak bisa hidup jika tidak dialiri listrik. Komputer juga tidak bisa beroperasi jika di dalam sistem komputernya tidak diberi program dasar atau operating system yang mengendalikan seluruh sistem bekerjanya kehidupan komputer. Jadi, listrik dan sistem operasi dapat dikatakan sebagai sumber kehidupan komputer atau sebagai ruhnya komputer. Sedangkan program aplikasi sangat diperlukan untuk kehidupan komputer agar ia dapat hidup layak sesuai fungsinya. Berbagai program operasi bisa kita masukkan ke dalam otak komputer agar ia bisa menjadi komputer yang pintar dan 
cerdas serta memiliki berbagai macam keahlian. Hanya saja, untuk bisa menciptakan komputer yang seperti itu, luar biasa susahnya.

\section{Kecerdasan Manusia}

Al-Qur'an mengajarkan bahwa kemajuan beragama terjadi melalui proses belajar. Sebenarnya seluruh pandangan filosofis dari al-Qur'an didasarkan atas proses belajar, yang mengangkat derajat manusia. Perintah pertama dari Allah kepada manusia adalah belajar. Perintah tersebut diungkapkan melalui wahyu pertama al-Qur'an surat al 'Alaq: 1.5.

"Bacalah dengan (menyebut) nama Tuhanmu yang Menciptakan; Dia Telah menciptakan manusia dari segumpal darah; Bacalah, dan Tuhanmulah yang Maha pemurah; Yang mengajar (manusia) dengan perantaran kalam [Maksudnya: Allah mengajar manusia dengan perantaraan tulis baca]; Dia mengajar kepada manusia apa yang tidak diketahuinya" (QS. al 'Alaq: 1-5).

Manusia bisa menjadi pandai dalam menyelesaikan segala permasalahan di dunia ini karena manusia mempunyai pengetahuan dan pengalaman. Pengetahuan diperoleh dari pendidikan (belajar). Semakin banyak bekal pengetahuan yang dimiliki seseorang, diharapkan akan lebih mampu dalam menyelesaikan permasalahan. Namun bekal pengetahuan saja tidak cukup, manusia juga diberi akal untuk melakukan penalaran, mengambil kesimpulan berdasarkan pengetahuan dan pengalaman yang dimilikinya. Tanpa memiliki kemampuan untuk menalar dengan baik, manusia dengan segudang pengetahuan dan pengalaman tidak akan dapat menyelesaikan masalah dengan baik. Demikian pula sebaliknya.

Keistimewaan manusia tidak terlepas dari akal dan kecerdasannya yang tak terbatas dan kesanggupannya untuk berhubungan dengan Tuhan. Akal nalar merupakan salah satu kekuatan fundamental dari jiwa manusia. Watak nalar dapat diartikan dengan mempersepsi. Aktivitas bernalar inilah yang membedakan manusia dengan binatang. Oleh karena itu, al-Qur'an sangat 
mengecam mereka yang tidak menggunakan akal nalamya, ancara lain seperti dijelaskan pada surat al-A'raaf ayat 179 dan surat al-Anfal ayat 22.

Berdasar kedua ayat di atas, kerja dan fungsi akal-lah yang membedakan manusia dengan binatang dan manusia dengan manusia. Kelebihan manusia treletak pada fungsi akal. Manusia yang paling buruk di sisi Allah SWT ialah manusia yang tidak mau mendengar, menuturkan dan memahami kebenaran dari penciptanya. Manusia yang seperti itu diibaratkan seperti binatang melata.

Al-Qur'an selalu mendorong akal pikiran dan menekankan pada upaya mencari ilmu pengetahuan serta pengalaman dari sejarah, dunia alamiah, dan diri manusia sendiri, karena Allah menunjukkan tanda-tanda kebesaranNya dalam diri manusia sendiri, amupun di luar dirinya. Oleh karena itu menjadi kewajiban manusia untuk menyelidiki dan mengamati ilmu pengetahuan yang dapat menghasilkan kecakapan dalam semua segi dari pengalaman manusia.

\section{Kecerdasan Buatan Manusia}

Kecerdasan buatan atau dalam bahasa Inggrisnya Artificial Intelligence sering disingkat AI merupakan studi tentang bagaimana membuat komputer dapat melakukan hal yang pada saat itu lebih baik dilakukan oleh manusia. Pada Artificial Intelligence, komputer dirancang untuk menjadi cerdas dan pintar sehinggga dapat melakukan pekerjaan seperti dan sebaik yang dilakukan oleh manusia dengan menirukan beberapa fungsi otak manusia, seperti pengertian bahasa, pengetahuan, pemikiran, penalaran, pemecahan masalah, bahkan sampai pada pengambilan keputusan (Rich dan Knight, 1991: 3).

Secara fundamental dan umum, definisi tentang kecerdasan buatan dapat dikelompokkan dalam empat kategori, yain:

1). Sistem yang dapat berpikir seperti manusia (Thinking Humanly).

2). Sistem yang dapat bertingkah laku seperti manusia (Acting Humanly).

3). Sistem yang dapat berpikir secara rasional (Thinking Rationally).

4). Sistem yang dapat bertingkah laku secara rasional (Acting Rationally) 
Bidang kecerdasan buatan berusaha untuk memahami entitasentitas cerdas pada diri manusia yang selanjutnya diimplementasikan dalam bentuk otomatisasi tingkah laku cerdas (intelligent) dengan media komputer. Tetapi tidak seperti bidang filosofi dan psikologi, yang juga berhubungan dengan kecerdasan, Artificial Intelligence berusaha membangun entitasentitas cerdas sesuai dengan pemahaman manusia.

Pada Artificial Intelligence, memungkinkan komputer bisa menerima pengetahuan melalui input manusia dan menggunakan pengetahuannya melalui simulasi proses penalaran dan berpikir manusia untuk memecahkan berbagai masalah. Walaupun tidak mungkin mendapatkan pengetahuan, pengalaman dan meneliti seperti manusia, tetapi komputer dapat memperoleh pengetahuan yang dibutuhkannya melalui upaya yang diberikan oleh seorang pakar manusia.

Input diberikan pada sistem yang menggunakan kecerdasan buamn berupa domain masalah. Pada sistem harus dilengkapi dengan sekumpulan pengetahuan yang ada pada basis pengetahuan. Pengetahuan dapat diperoleh dari para pakar, atau mungkin secara otomatis dari pustaka, atau dari basis data. Sistem harus memiliki mesin inferensi atau mesin penentu (inference engine) agar mampu mengambil kesimpulan berdasarkan fakta atau pengetahuan. Jadi, mesin inferensi bertindak sebagai eksekutif yang memutuskan berjalannya sistem. Output yang diberikan berupa solusi masalah sebagai hasil dari inferensi.

Kenyataannya hampir semua produk program kecerdasan buatan yang dilaksanakan dengan teknik pelacakan dan pencocokan pola berdasar basis pengetahuan yang diberikan kepadanya, meng-arah ke suatu kesimpulan bahwa komputer tidak benar-benar pintar. Seberapa pun banyaknya informasi yang diberikan user kepada komputer, dengan proses yang pengolahan informasi yang sangat cepat berdasar aturan dan kriteria yang berlaku, komputer tetap bisa menemukan suatu solusi. Semua yang dilakukannya merupakan percobaan atas berbagai alternatif dan usaha menemukan beberapa kombinasi yang cocok dengan kriteria terancang. Bila semua sudah dikerjakan, maka secara khusus solusi bisa dicapai. Dengan 
demikian, walaupun komputer tidak betul-betul pintar, tampaknya tidak salah kalau kita menyebutkan bahwa komputer seperti berpikir dan sering memberikan solusi yang menakjubkan.

\section{Pohon Ilmu Kecerdasan Buatan}

Kecerdasan buatan merupakan kumpulan konsep dan ide yang berkaitan dengan perkembangan sistem cerdas. Konsep dan ide yang berkaitan dengan perkembangan sistem cerdas tersebut dapat dikembangkan dalam area yang berbeda dan diterapkan untuk domain yang berbeda. Oleh karena itu, untuk memahami lingkup kecerdasan buatan, kita perlu melihat kelompok area aplikasi kecerdasan buatan yang dapat disebut keluarga $\mathrm{Al}$.

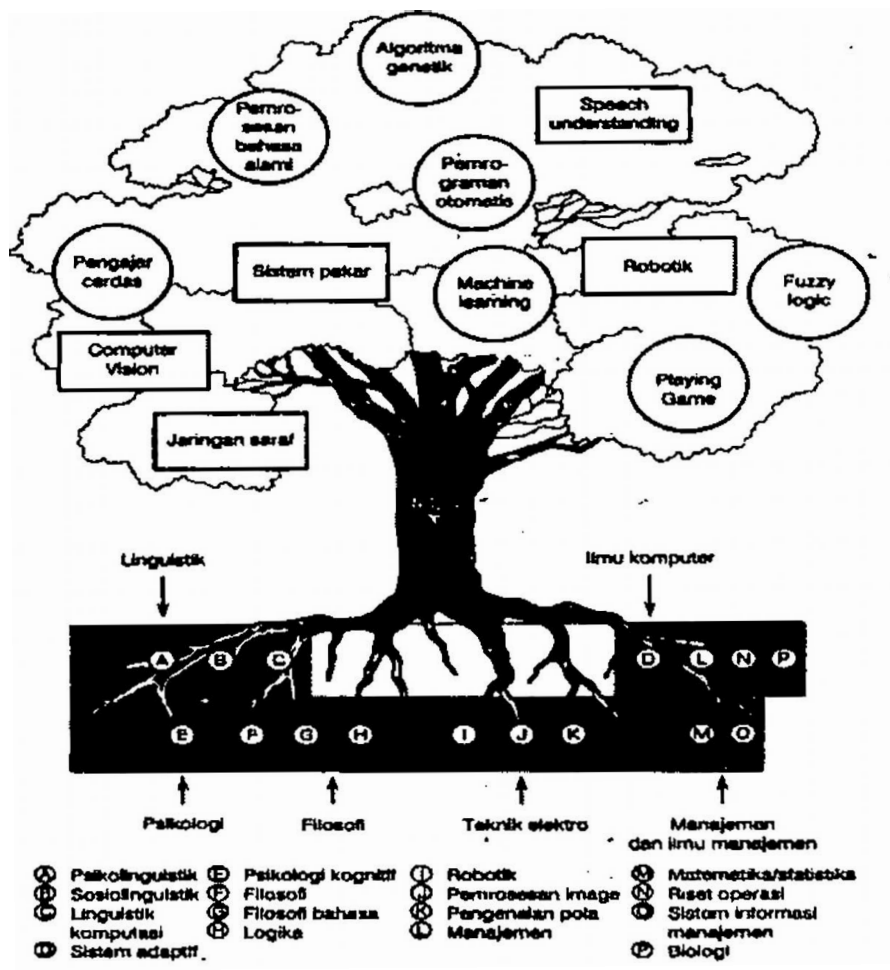

Gambar 1. Pohon AI: Disiplin AI (akar) dan Aplikasi AI (daun) (Turban, 2005: 70\%). 
Makin pesatnya perkembangan teknologi menyebabkan adanya perkembangan dan perluasan lingkup yang membutuhkan kehadiran kecerdasan buatan. Karakteristik cerdas sudah mulai dibutuhkan di berbagai disiplin ilmu dan teknologi. Kecerdasan buatan tidak hanya dominan di bidang ilmu komputer (informatika), namun juga sudah merambah di berbagai disiplin ilmu yang lain.

Cabang-cabang $\mathrm{AI}$ seperti yang digambarkan pada pohon $\mathrm{AI}$, secara singkat dapat dideskripsikan seperti berikut:

1. Sistem Pakar (Expert System)

Sistem yang menggunakan pengetahuan manusia yang terekam dalam komputer untuk memecahkan persoalan yang biasanya memerlukan keahlian manusia.

2. Pemrosesan Bahasa Alami (Natural Language Processing)

Dengan menggunakan teknologi pemrosesan bahasa alami (NLP) ini mernungkinkan pengguna komputer berkomunikasi dengan suatu komputer menggunakan bahasa aslinya (bahasa sehari-hari).

3. Pengenalan Ucapan (Speech Understanding)

Pengenalan dan pemahaman bahasa lisan oleh komputer. Jadi, melalui pengenalan ucapan diharapkan manusia dapat berkomunikasi dengan komputer dengan menggunakan suara

4. Robotika dan Sistem Sensor (Robotics \& Sensory Systems)

Robot cerdas memiliki beberapa jenis perangkat sensor, misalnya kamera, yang mengumpulkan informasi tentang operasi dan lingkungan robot.

5. Computer Vision

Tujuan dasar dari comprter vision adalah mencoba untuk menginterpretasikan gambar atau obyek-obyek tampak melalui komputer, bukannya menghasilkan gambar. 
6. Intelligent Computer-Aided Instruction

Sistem CAI cerdas dikembangkan untuk menciptakan pengajar komputerisasi yang membentuk teknik pengajaran yang sesuai untuk pola pembelajaran siswa (induvidual).

7. Jaringan Syaraf Tiruan (Artifical Neural Network)

Sekumpulan model matematika yang mensimulasikan cara otak manusia berfungsi.

8. Game Playing

Merupakan area yang sempurna untuk menyelidiki strategi dan heuristik baru dan untuk mengukur hasilnya. Deep Blue adalah contoh bagus untuk pengembangan yang berhasil.

9. Penerjemahan Bahasa

Penerjemahan otomatis menggunakan komputer untuk menerjemahkan kata dan kalimat dari satu bahasa ke bahasa lain tanpa banyak campur angan manusia.

10. Fuzzy Logic

Merupakan teknik untuk mengolah istilah linguistik. Dalam fuzzy logic, nilai benar atau salah digantikan dengan derajat pada himpunan keanggotaan.

\section{Algoritma Genetika (Genetic Algorithm)}

Merupakan metode cerdas menggunakan komputer yang mensimulasi proses evolusi Darwin dan operasi genetika atas kromosom untuk menemukan pola dari sekumpulan data.

12. Agen Cerdas (Intelligent Agents)

Program kecil yang terletak pada komputer untuk melakukan tugas tertentu secara otomatis. Program deteksi virus adalah contoh yang bagus.

\section{Teknologi Kecerdasan Buatan Masa Depan}

Para peneliti bidang AI setiap tahun bisa lebih mendekati komputer pintar, tetapi masih banyak masalah yang harus dijawab. Misalnya, 
bagaimana Anda bisa mencerminkan keterampilan dalam menangani masalah manusia, kemam-puan belajar, selera, imajinasi, emosi, kreativitas, dan keberanian. Untuk menjawab masalah di atas, para ahli kembali ke bidang yang berkaitan, seperti filosofi, psikologi, linguistik, dan sain syaraf (neuro science) serta tentu sain komputer sendiri. Dengan demikian, akan lahir bidang sain kognitif antardisiplin.

Barangkali tidak akan terlalu menjadi persoalan bila kita belum bisa meni-rukan kerja otak manusia seutuhnya. Tujuan penduplikasian manusia tidak akan pernah terwujud melalui teknologi canggih apapun, termasuk teknologi kecerdasan buatan. Lebih lanjut, kita hanya sekadar bisa meniru sebagian kerja otak manusia. Ini akan lebih berguna dan lebih baik daripada tidak sama sekali karena tujuan utama kim membuat komputer pintar dan cerdas bukan untuk menyamai atau menggantikan manusia, tetapi hanya sekedar menjadi alat bantu manusia dalam menjalani kehidupannya di dunia.

Selanjutnya, apa yang akan terjadi dengan teknologi kecerdasan buatan di masa mendatang? Banyak sekali. Penelitian dan pengembangan teknik kecerdasan buatan akan terus berlangsung dan seluruh subbidang akan semakin maju dan semakin baik. Teknik software baru akan mulai tersingkap. Alat pengembangan software (software tool) yang lebih canggih akan memudahkan pengembangan sistem pakar dan program-program kecerdasan buatan lainnya.

Konsep integrasi ilmu sudah mulai menjamur. Tidak menutup kemungkinan konsep itu akan terjadi pada pengembangan teknologi kecerdasan buatan ke depan. Seni kolaborasi antar sub-bidang teknologi kecerdasan buatan untuk membangun sistem lanjutan terintegrasi akan menjadi topik menarik bagi para peneliti AI. Akan banyak bermunculan beberapa teknologi lanjutan sebagai wujud dari aplikasi nyata dari integrasi sistem cerdas guna menangani jangkauan informasi yang lebih luas dan memecahkan permasalahan yang lebih kompleks.

Teknologi kecerdasan buatan merupakan pene-muan teknologi yang sangat canggih. Teknologi kecerdasaan buatan bukan satu-satunya obat 
muja-rab yang bisa menyembuhkan segala penyakit. Karenanya, kita tidak boleh terlalu mengharapkan suatu keajaiban. Kita harus melihat kenyataan yang sedang dihadapi. Teknologi kecerdasan buatan mungkin bisa memberikan solusi yang menyerupai keajaiban, tetapi hanya sekedar semu dan bukan benar-benar keajaiban. Teknologi kecerdasan buatan hanya memberikan kemajuan evolusioner dan bukan kemajuan revolusioner. Dan yang perlu diyakini bahwa teknologi kecerdasan buatan merupakan suatu teknologi yang memesona dan luar biasa. Menarik untuk dikaji dan dipelajari.

\section{Simpulan}

Penelitian-penelitian kecerdasan buatan mempunyai tujuan ganda, yaitu menciptakan komputer yang cerdas dan memahami cara kerja otak manusia. Dengan teknologi kecerdasan buatan, komputer dapat dibuat cerdas, karena dalam melakukan tugas-tugasnya komputer mampu memperlihatkan perilaku yang dapat kita sebut cerdas sekiranya hal itu dilakukan oleh manusia.

Penelitian dan pengembangan teknik kecerdasan buatan akan yang terus berlangsung dan seluruh subbidang akan semakin maju dan semakin baik. Walaupun usianya sudah tua, teknik kecerdasan buatan tetap merupakan teknologi bayi yang masih memiliki banyak PR untuk diselesaikan dan masih berkembang untuk memperoleh kemajuan yang lebih pesat. Seni kolaborasi antar sub-bidang teknologi kecerdasan buatan untuk membangun sistem lanjutan terintegrasi akan menjadi topik menarik bagi para peneliti AI untuk pengembangan teknologi AI di masa mendatang.

\section{Daftar Pustaka}

Abdullah, Mas Udik. 2005. Meledakkan IESQ dengan Langkah Taqwa dan Tawakal. Jakarta: Zikrul Hakim.

Al-Kumayi, Sulaiman. 2006. 99Q Kecerdasan 99. Cara Meraih Kemenangan dan Ketenangan Hidup Lewat Penerapan 99 Nama Allah. Jakarta: Hikmah, Kelompok Mizan. 
Arhami, Muhammad. 2005. Konsep Dasar Sistem Pakar. Yogyakarta: Andi Offset.

Bagir, Zainal Abidin. Dkk. 2006. Ilmu, Etika, dan Agama. Menyingkap Tabir Alam dan Manusia. Yogyakarta: Center for Religious and Crosscultural Studies (CRCS).

Barbour, Ian G. 2005. Menemukan Tuhan dalam Sains Kontemporer dan Agama. Terjemahan dari Nature, Human Nature, and God oleh Fransiskus Borgias M. Bandung: Mizan.

Chang, Chin-Liang. 1985. Introduction to Artificial Intelligence Techniques. Alih bahasa : Bambang Sridadi. Jakarta: Erlangga

Departemen Pendidikan dan Kebudayaan. 1991. Kamus Besar Bahasa !ndonesia, edisi ke-2. Jakarta: Balai Pustaka. hal.15.

Desiani, Anita dan Muhammad Arhami. 2006. Konsep Kecerdasan Buatan. Yogyakarta: Andi Offset.

Efendi, Agus. 2005. Revolusi Kecerdasan Abad 21: Kritik MI, EI, SQ, AQ \& Successful Intelligence Atas IQ. Bandung Alfabeta (Anggota IKAPI).

Encarta Encyclopedia: Photo Researchers, Inc./Hank Morgan/Science Source. Microsoft (B) Encarta (B) 2006. (C) 1993-2005 Microsoft Corporation. All rights reserved.

Fausett, Laurene. 1994. Fundamentals of Neural Networks: Architectures, Algorithms, and Applications. USA: Prentice-Hall, Inc.

Gen, Mitsuo, Cheng, Runwei. 1997. Genetic Algorithms and Engineering Design. John Wiley \& Sons, Inc.

Hermawan, Arief. 2006. Jaringan Syaraf. Tiruan: Teori dan Aplikasi. Yogyakarta: Andi Offset.

Kristanto, Andri. 2004. Kecerdasan Buatan. Yogyakarta: Graha Ilmu.

Kusrini. 2006. Sistem Pakar, Teori dan Aplikasi. Yogyakarta: Andi Offset.

Kusumadewi, Sri. 2003. Artificial Intelligence (Teknik dan Aplikasinya). Yogyakarta: Graha Ilmu.

Kusumadewi, Sri. dan Hari Purnomo 2005. Penyelesaian Masalah Optimasi dengan Teknik-teknik Heuristik. Yogyakarta: Graha Ilmu.

Mustofa, Agus. 2005. Menyelam ke Samudera Jiwa \& Ruh. Surabaya: PADMA press. 
Pal, Sankar P. dan Dwijesh K. Dutta Majumder. 1989. Fuzzy: Pendekatan Matematik untuk Pengenalan Pola. Jakarta: UI-press.

Pandjaitan, Lanny W. 2007. Dasardasar Komputasi Cerdas. Yogyakarta: Andi Offset.

Pasiak, Taufiq. 2002. Revolusi IQ/EQ/SQ: Antara Neurosains dan AlQur'an. Bandung: Mizan.

Puspaningrum, Diyah. 2006. Pengantar Jaringan Syaraf Tinuan. Yogyakarta: Andi Offset.

Qardhawi, Yusuf. 1998. Al-Qur'an Berbicara tentang Akal dan Pengetahuan. Jakarta: Gema Insani.

Rahman, Afzalur. 1989. Al.Qur'an Sumber Ilmu Pengetahuan. Jakarta: Bina Aksara.

Rich, Elaine dan Kelvin Knight. 1991. Artificial Intelligence. New York: McGraw-Hill Inc.

Sukidi. 2004. Rahasia Sukses Hidup Bahagia. Kecerdasan Spiritual Mengapa SQ Lebih Penting daripada IQ dan EQ. Jakarta: Gramedia Pustaka Utama.

Setiawan, Kuswara. 2003. Paradigma Sistem Cerdas (Jaringan Syaraf Tinuan, Logika Fazi dan Algoritma Genetika). Malang: Bayumedia Publishing.

Setiawan, Sandi. 1993. Artificial Intelligence. Yogyakarta: Andi Offset.

Siang, Jong Jek. 2005. Jaringan Syaraf Tiruan dan Pemrogramannya Menggunakan Matlab. Yogyakarta: Andi Offset.

Suparman dan Marlan. 2007. Komputer Masa Depan. Yogyakarta: Andi Offset.

Suyanto. 2002. Intelejensia Buatan. Bandung: STT Telkom.

Suyoto. 2004. Intelegensi Buatan: Teori dan Pemrograman. Yogyakarta: Gava Media.

Suyanto. 2005. Algoritma Genetika dalam MATLAB. Yogyakarta: Andi Offset.

Turban, Efraim. J.E.Aronson \& Ting-Peng Liang. 2005. Decision Support Systems and Intelligent Systems. $7^{\text {th }}$ Ed. USA:Prentice-Hill Internasional, Inc.

Wahono, Romi Satria. 2003. Pengantar Software Agents: Teori dan Aplikasi. (Online), www.ilmukomputer.com. 
Walter Brenner, Rudiger Zarnekow, and Hartmut Wittig. 1998. Intelligent Software Agents: Foundation and Applications. Springer-Verlag.

Widodo, Thomas Sri. 2005. Sistem Neuro Fuzzy untuk Pengolahan Informasi, Pemodelan, dan Kendali. Yogyakarta: Graha Ilmu.

Winston, Patrick Henry. 1993. Artificial Intelligence. Third Edition. USA: Addison-Wesley Publishing Company.

Yahya, Harun. 2002. Allah is Known through Reason / Mengenal Allah Lewat Akal. Terjemahan oleh Muhammad Shadiq. Jakarta: Robbani Press.

Zaleski, Jeff. 1999. Spiritualitas Cyberspace : Bagaimana Teknologi Komputer mempengaruhi Keberagaman Kita. Bandung: Mizan.

Zohar, Danah dan Ian Marshall. 2002. SQ: Memanfaatkan Kecerdasan Spiritual dalam Berpikir Integralistik dan Holistik untuk Memaknai Kehidupan. Bandung: Mizan.

www.beritaiptek.com. Artikel iptek, Robot dan Budaya. (Online), diakses 30 Desember 2005.

QS. al-A'raaf ayat (7) : 179

QS. al-Anfal (8) : 22.

QS. al 'Alaq (96): 1.5

QS. ath Thalaq (65): 12

QS. Thaahaa (20): 98 